\title{
THE A.P.C. VIRUSES
}

\author{
By Elisabeth Zaiman, M.A., B.M., B.Ch. \\ Temporary Member of Scientific Staff of Medical Research Council, Virus Reference Laboratory, Central Public Health \\ Laboratory, Colindale, London, N.W.9
}

The name A.P.C.- short for adenoidal-pharyngeal-conjunctival-has been given to a recentlydescribed group of viruses, which have mostly been isolated from tissue cultures of surgicallyremoved human adenoids and tonsils, and from pharyngeal and conjunctival secretions of patients suffering from acute respiratory infections, and conjunctivitis. These viruses have also been known as A.D. (adenoid-degenerating), A.R.D. (acute respiratory disease), and R.I. (respiratory illness) agents. This last term is currently used by some investigators.

\section{History}

The first report of isolations of viruses of the A.P.C. group appeared in December 1953 . Rowe et al. ${ }^{1}$ were studying the growth of surgicallyremoved human tonsils and adenoids in rollertube tissue cultures, in the hope that such cultures would prove a suitable medium for the cultivation of the common cold virus. They observed a spontaneous degeneration occurring in many of the epithelial out-growths, and later found that this degeneration could be serially transmitted in other tissue cultures, by passage of fluid from tubes containing the abnormal cells. Further investigation showed that the degenerative effect was due to agents which would pass through bacteria-retaining filters, would not grow on bacteriological media, and caused no recognizable disease in any of the numerous laboratory animals tested. However these agents regularly caused characteristic changes in epithelial-type cells in cultures of numerous normal human and some animal tissues, and also in cultures of the strain $\mathrm{HeLa}^{2}$ of human epidermoid carcinoma cells. These changes were specifically neutralized by antisera produced by hyperimmunizing rabbits against the viruses, but no immunological relationship to any other known group of viruses could be demonstrated. Some human sera, and gamma globulin, also neutralized the cytopathogenic effect of the viruses, sometimes in high dilutions. The relation of these ' adenoid-degenerating' agents to clinical human illness was so far unknown.
In January I954, Hilleman and Werner ${ }^{3}$ reported the isolation in tissue-culture of a viruslike agent $\left(\mathrm{RI}_{\mathrm{I}}-67\right)$ from throat washings from cases of 'primary atypical pneumonia' and ' acute respiratory disease' among military recruits. This agent caused a'characteristic change in the appearance of cultures of human adult tracheal epithelium, and also in cultures of strain HeLa cells, which was serially transmissible. Fluids from infected cultures could be used as antigen in complement-fixation tests with sera from these patients, and rises in complement fixing antibodies against this antigen were demonstrated between acute and convalescent specimens. Rises in antibody which neutralized the cytopathogenic changes in tissue cultures wero also demonstrated in paired sera from patients The agent isolated would not grow on artificiof media, and was not infective for laborator animals or developing chicken embryos. NG serological relationship to any other human respiratory virus could be shown, and no antibody rises against this new agent appeared in paired sera from patients with virus diseases of known aetiology, although some sera contained antibody without a change in titre against the new virus-like agent. It was later shown that a serological relationship existed between Hilleman's ' RI-67' virus, and the 'A.D.' agents described by Rowe, Huebner et al. ${ }^{1}$

The publication of these two reports, following so closely on each other, stimulated a great deal of interest, particularly among investigators of respiratory disease. It seemed possible that these new viruses might clarify the problem of the many respiratory infections which are not due to bacteria, or any of the previously described respiratory viruses such as influenza and the psittacosis-ornithosis group. Many outbreaks of res- N piratory illness have since been investigated, by inoculation of specimens into tissue cultures, and by serological tests. Viruses of the A.P.C. group have been isolated in Britain,4, 5,6 Canada $^{7}$ and Sweden $^{8}$, as well as in the U.S.A., and there is serological evidence for their presence in France also. ${ }^{9}$ The literature is not yet very extensive, 
but there is already a fair knowledge of the properties, ecology and epidemiology of these viruses, and some of the disease pictures associated with them.

\section{Properties}

The properties of the A.P.C. viruses have been investigated in some detail by the two groups of workers who originally isolated the viruses, and many of their findings have been confirmed in other laboratories. It is convenient to describe these properties under three headings; chemical and physical, host range, and serological. The earliest strains to be isolated have naturally been the most extensively studied, and it is possible that not all the characteristics to be mentioned can be applied to all members of the group. The following account includes all the work that has been published to date, though the author is aware of some unpublished studies which may in due course lead to a revision of some of the details stated.

\section{Physical and Chemical ${ }^{10}, 11,12$}

The A.P.C. viruses are resistant to ether and all antibiotics so far tested. They pass through bacteria-retaining filters with no appreciable loss in activity. Infectivity is destroyed by heat at $56^{\circ} \mathrm{C}$ for 30 minutes but is unaffected by at least three cycles of quick freezing and thawing. The viruses are stable for long periods at $-30^{\circ} \mathrm{C}$, and have remained infective after four months at $2^{\circ} \mathrm{C}$. One strain has been examined for its stability at various $\mathrm{pH}$ levels; exposure to $\mathrm{pH}_{3} . \mathrm{I}$ and $\mathrm{pH}_{9.4}$ resulted in only slight loss of infectivity, but $\mathrm{pH} 2.0$ and $\mathrm{pH}$ Io. I produced complete inactivation.

Electron microscope preparations ${ }^{12}$ (studied in two strains), contained numerous spherical bodies of uniform size and shape, and also a few 'doughnut' forms, measuring $90 \mu( \pm 4 \mu)$. Estimation of the virus particle size by pseudo-velocity sedimentation experiments was about $109 \mu$ ( $\pm 6 \mu$ ); while filtration through Gradocol membranes indicated a size between 80 and $120 \mu$. The complement fixing antigen which the A.P.C. viruses produce, sediments less rapidly than the virus particles, and can be separated by differential centrifugation, or by filtration through Gradocol membranes which hold back the virus particles.

\section{Host Range 1, 3, 4, 8, 10, 11, 13}

A.P.C. viruses have not been found to cause any recognizable illness in any of the numerous laboratory animals which have been inoculated by a variety of routes. Developing chicken embryos are not affected by these agents and there is no evidence of virus multiplication or haemagglutinin formation in any of the fluids of the embryonated hen's egg.

A.P.C. viruses cause a characteristic degenerative effect on cells of a number of human and animal tissues grown in culture. The change affects both epithelial and fibroblast-like cells, but appears very much earlier and progresses much more rapidly in the former. The degeneration appears first at the periphery of the cell sheet, and in small scattered foci, after a time depending on the size of the inoculum. The cells become enlarged and round and highly refractile, with clearly defined outlines. There is a marginal zone of clear cytoplasm, and a densely granular centre in which nuclear structures cannot be recognized. The affected cells clump together, and eventually fall off the glass, into the fluid culture medium, but do not appear to disintegrate, as happens with cells infected with, for example, poliomyelitis virus. In infected cultures stained with haematoxylin and eosin, the cytoplasm stains deep pink, and the nuclear chromatin dark purplish black. The cells have swollen eosinophilic nuclei often appearing to contain basophilic inclusions. The nuclear chromatin is sometimes fragmented, and sometimes in a dense, deeply staining, pyknotic mass.

This cytopathogenic effect is quite different from that caused by any other virus so far described and is very easily recognizable. It has beenobserved in human adult tracheal epithelium, human adenoid, tonsil and kidney; human embryo nose, pharynx,' palate, tongue, trachea, skin, muscle, pancreas, lung and kidney; in strain HeLa cells; in monkey kidney; in rabbit trachea and kidney; in cotton rat muscle and trachea; suckling hamster trachea, lung, kidney, skin and muscle. Strain HeLa cells are widely available and have proved convenient for studies on these viruses and most of the work that has been done so far has made use of these cultures. An interesting phenomenon of the growth of A.P.C. viruses in $\mathrm{HeLa}$ cells is the concurrent production of lactic acid, so that when an indicator is incorporated in the nutrient medium, infected cultures are seen to have a lower $\mathrm{pH}$ than the controls. This acid production is not seen in infected cultures of other tissues.

\section{Serological Properties}

Specific antisera against strains of A.P.C. virus can be prepared by hyperimmunization of rabbits with infected tissue culture fluid. By means of cross-neutralization tests in tissue culture, Huebner's group $1,10,11$ have distinguished a number of distinct immunological types. Serum containing antibody to one of these types will not 
neutralize the cytopathogenic effect of any other type. The latest report ${ }^{14}$ lists 14 distinct serotypes of which 12 are from a variety of human sources and two are simian.

A.P.C. viruses possess complement-fixing antigens, which are soluble, and are produced in comparatively large amounts in the fluid medium of infected tissue cultures. The complementfixing antigens are group-specific, but not typespecific. There is extensive cross-reaction between the complement-fixing antigens produced by the different sero-types. Both complementfixing and neutralizing antibodies can be demonstrated in sera of patients who have undergone an infection with a virus of the A.P.C. group, but neutralizing antibodies persist much longer. As with other virus infections, therefore, the demonstration of complement-fixing antibody in serum, suggests a relatively recent exposure to infection, while the presence of neutralizing antibody merely indicates past infection. With paired acute and convalescent sera, however, a fourfold or greater rise in specific neutralizing antibody gives an indication of the serotype responsible for the infection, while a similar rise in complement fixing antibody titre can only point to infection by one of the A.P.C. group of viruses. Both tests have considerable value in epidemiological studies, but the complement fixation test is much quicker to set up and to read, and needs fewer special laboratory facilities.

\section{Association of A.P.C. Viruses with Clinical Illness}

A.P.C. viruses have been isolated from a variety of sources, including material from clinically healthy people, and their relationship to human disease is by no means well-defined.

Types I, 2, 5 and 6 have been isolated almost exclusively from degenerating adenoids and tonsils in tissue culture, the first two most frequently and type 6 rarely. In a large series of tonsils and adenoids investigated by Huebner's group $^{10}$, A.P.C. viruses were isolated from more than $5^{\circ}$ per cent. The recovery rate has not been so high in the smaller numbers studied in Britain ${ }^{4}, 5$.

Hilleman's ' RI-67' virus', which has since been classified as A.P.C. type $4^{10}$, was first isolated from a case of 'primary atypical pneumonia' unassociated with cold agglutinins. It was subsequently found to be associated with other cases of similar illness among military recruits, and also with many cases of ' acute respiratory disease.' This is a term used in the American literature, following the U.S. Army Commission on Acute Respiratory Diseases, to describe acute infections of the upper respiratory tract not due to influenza viruses, but difficult to distinguish clinically fro influenza. It corresponds to ' febrile catarrh' als described by Stuart-Harris ${ }^{15}$. Using Hillemants antigen, Dingle and his colleagues at Cleveland performed retrospective serological investigation on sera stored from cases of 'acute respiratogy disease ' during World War II, and from humag volunteers experimentally infected in a study this syndrome in 1945. The results showed clear association between RI-67 or A.P.C. ty 4 , and this type of infection ${ }^{16}$. A.P.C. type 4 h\%क् since been implicated, by isolation and by serolog in a number of outbreaks of respiratory illness. particularly among military recruits ${ }^{17-22}$, but alş in civilian population groups ${ }^{23}, 24$. It must pointed out that in many of the outbreaks studied, a certain number of infections were found to due to influenza viruses, and there were also hy proportion, clinically similar, whose aetiology remained undetermined. This subject has beẹn extensively reviewed recently by Dingle aris Feller ${ }^{26}$.

Type 3 A.P.C. virus was first isolated froํำ nasal washings of volunteers inoculated with nasal secretions from a person with a 'common cold" Shortly afterwards it was demonstrated in coफ़े cunctival exudates of two sufferers from unilatera] conjunctivitis. Subsequently it was found to the cause of a syndrome comprising pharyngitis with conjunctivitis, fever, and enlarged cer lymph-nodes, in staff and patients of a childrtins hospital ${ }^{27}$. This entity has been named ' pharyngoconjunctival fever,' and several outbreaks, main among children, have since been investigated arget described $^{28,29}$. Type 3 A.P.C. was found in the American cases, but a different type, as vet unidentified, but not any of types i to 6 , w $\overrightarrow{\mathrm{G}_{5}}$ isolated from similar cases in Britain.*

Type 3 A.P.C. virus has also been isolated fro高 a few patients with ' acute respiratory disease and from a number of cases of follicular conjunct vitis in the U.S.A., and also in Canada ${ }^{30,31}$.

Types $I$ to 6 have all been inoculated in human volunteers by Huebner's group ${ }^{10}$, and type 4 by Hilleman and his colleagues also ${ }^{25}$, mains using tissue culture fluids containing active virus. Few clinical manifestations were observed after intra-nasal administration, and it was diffict to recover virus from nasal or throat washings, bet serological evidence of infection in the form of $t$ appearance or increase of complement-fixing and neutralizing antibodies, was found in most in stances. In later experiments ${ }^{32}$, conjunctivifuss was experimentally induced by conjunctival inoculation of type 3 virus, and the infecting agegt could be recovered from conjunctival secretions of

* This has now been identified as Type 7 . 
the volunteers. Further studies, with a vaccine made from type 3 virus inactivated by heat and formalin, showed that it was possible to stimulate immunity to subsequent conjunctival challenge. Inoculation of human volunteers in Britain with A.P.C. viruses produced more obvious clinical infections $s^{5}$ than those described by the American workers.

A.P.C. types 7 to 14 have been identified more recently, and been studied less extensively than the first six.

Type 7 was found, in association with types 3 and 4 , among cases of ' acute respiratory disease' in a military camp in California ${ }^{20}$ by Berge and his colleagues. These workers made an interesting observation; that type 4 viruses were most often associated with illnesses involving the lower respiratory tract, while infections confined to the upper respiratory tract were more often caused by type 7 .

Type 8 virus was first isolated from conjunctival secretions of patients with epidemic kerato-conjunctivitis ${ }^{33}$, and there is serological evidence for the association between this infection and type 8 virus in a report from Canada ${ }^{31}$.

The remaining A.P.C. types have been defined so recently ${ }^{14}$ that there is little known about their association with human disease. Types 13 and I4 have been isolated only from simian species.

\section{Serological Surveys}

Attempts have been made to estimate the prevalence of infection with A.P.C. viruses by assessment of antibody levels in sera collected from various population groups.

Complement-fixing antibodies have been found in a high proportion of sera from military personnel $\mathrm{l}^{4}, 13,18,19,34$, hospital patients ${ }^{4}, 11,13$, students $^{4}, 13,24$ and other civilian groups ${ }^{4}, 9,13,23$. This indicates that infection with this group of viruses is widespread, at least among the groups tested.

Neutralization tests performed in America ${ }^{\mathbf{1 0}}$ and Britain ${ }^{13}$ against types $I$ to 6 , have shown that antibodies against all six types are present in sera of all age groups tested. In the survey of more than 200 sera from hospital patients of all ages, Huebner's group ${ }^{10}$ found that more than 50 per cent. of infants aged 6 to I I months had antibody to at least one type, and 30 per cent. to two or more. Furthermore, among the 16 to 34 agegroup, the majority had antibodies to at least three types, while subjects over 40 years of age nearly all had antibody to four types, and the majority to five. Antibodies against the different types varied among the age-groups: for example, infants most frequently had antibodies against types $I$ and 2 ; type 4 antibodies were found in only 25 per cent. of the group 6 to 15 years old, but were present in 70 per cent. of those aged I 6 to 34 . It seems clear that the various A.P.C. types have been prevalent in different years, and are not all in wide circulation simultaneously.

\section{Summary}

It is difficult to summarise concisely the information at present available about the A.P.C. group of viruses. Some aspects have been studied much more completely than others, some of the work reported awaits confirmation, and a great many questions are yet unanswered.

The characteristics of the group which have been defined to date are: the production of characteristic cytopathogenic changes in tissue cultures of human and some animal tissues, notably in the epithelial cells; apathogenicity for laboratory animals ; resistance to ether and antibiotics; and the production of a soluble complement-fixing antigen shared by all immunological types.

Fourteen distinct immunological types have so far been distinguished by cross-neutralization tests. Types $I$ and 2, and to a lesser extent, 5 and 6, are latently present in numbers of surgically removed adenoids and tonsils, but it is not known how long they persist in these situations, or to what extent they are connected with the chronic respiratory disease which is usually the reason for the removal of these organs. Type 3 has been unequivocally associated with "pharyngo-conjunctival fever'; type 4 is certainly the cause of a number of acute respiratory illnesses, including syndromes indistinguishable from influenza, primary atypical pneumonia, acute pharyngitis, and 'common cold'; type 7 has recently been incriminated in similar infections; and type 8 appears to be responsible for at least some cases of epidemic keratoconjunctivitis.

Serological studies have indicated that infections with at least six of the types have been experienced by many people in all age groups of the populations so far investigated.

The discovery of the A.P.C. group of viruses has helped to clarify the aetiology of acute respiratory illnesses, though many pieces of the jigsaw puzzle of non-bacterial respiratory disease remain to be filled in. These viruses must also be added to the list of those causing diseases of the eye.

It remains to be seen how long this rapidlyexpanding group will be called by the initials A.P.C. It is not impossible that further study will associate it with many more infections at present labelled 'virus' for want of a more precise diagnosis. It is certain that the full range of these interesting agents is only beginning to be explored. References continued on page 447 


\section{A new monograph entitled}

\section{Anaesthetic Accidents}

\section{by V. KEATING}

M.B., B.Ch., D.A., F.F.A. R.C.S.

Consultant Anaesthetist and Lecturer in Anaesthetics,

University College Hospital of the West Indies

This work correlates current opinion on the prevention, diagnosis and treatment of the immediate and remote complications of general and regional anaesthesia, with each section of the book illustrated by the author's personal observations. Anaesthetic accidents are relatively uncommon, but when they do occur they may lead to the death or life-long invalidism of the patient; thus a knowledge of the experience of others and pertinent

$v i i+261 p p$.

13 illustrations

(1956) 25s. net experimental facts are important.

\section{A new monograph entitled}

\section{Postural Drainage}

by E. WINIFRED THACKER, M.C.S.P.

Superintendent Physiotherapist, Harefield Hospital

Foreword by Mr. T. HOLMES SELLORS, M.Ch., F.R.C.S.

Thoracic Surgeon, Middlesex Hospital

In this small well-illustrated monograph the author gives full and careful instructions which should be followed in the pre- and post-operative treatment by physiotherapy of medical and surgical chest cases. It should be a valuable help to all physiotherapists and others who have to treat patients in whom postural drainage is required.

$v i i i+56 p p$.

50 illustrations (1956) 8s. 6d. net

\section{Lloyd-Luke \\ (Medical Books) Ltd.,

Continued from page 429-Elisabeth Zaiman, M.A., B.M., B.Ch.

\section{REFERENCES}

I. ROWE, W. P., HUEBNER, R. J., GILMORE, L. K. PARROTT, R. H., and WARD, T. G. (1953), Proc. Soc, exp. Biol., 84, 570 .

2. SCHERER, W. F., SYVERTON, J. T., and GEY, G. O. (1953), F. exp. Med., 97, 695.

3. Hilleman, M. R., and WERNER, J. H. (1954), Proc. Soc. exp. Biol., 85, I83.

4. ZAIMAN, E., BALDUCCI, D., and TYRRELL, D. A. J. (1955), Lancet, Sept. 17, p. 595.

5. PEREIRA, H. G., personal communication.

6. ANDREWS, B. E., personal communication.

7. ORMSBY, H. L. (1955), Canad. F. publ. Hlth, 46, 500.

8. KJELLEN, L. (1955), Arch. f. ges. Virusforsch., 6, 45.

9. SOHIER, R. (1956), Ann. Inst. Pasteur, 90, 222.

Io. HUEBNER, R. J., ROWE, W. P., WARD, T. G., PARROTT, R. H., and BELL, J. A. (1954), New Engl. F. Med., 25I, 1077.

I I. ROWE, W. P., HUEBNER, R. J., HARTLEY, J. W., WARD, T. G., and PARROTT, R. H. (1955), Amer. F. Hyg., 6i, 197.

12. HILLEMAN, M. R., TOUSOUMIS, and WERNER, J. H. (I955), Proc. Soc. exp. Biol., 89, 587.

13. BALDUCCI, D., ZAIMAN, E., and TYRRELL, D. A. J., Brit. F. exp. Path., in press.

14. ROWE, W. P., HARTLEY, J. W., and HUEBNER, R. J. (1956), Proc. Soc. exp. Biol., 91, 260.

15. STUART-HARRIS, C. H. (1953), 'Influenza,' London, Edward Arnold.

16. DINGLE, J. H., GINSBERG, H. S., BADGER, G. F. JORDAN, W. S., JR., and KATZ, S. (r954), Tr. Assn. Am. Phys., 67, 149.

17. HILLEMAN, M. R., WERNER, J. H., ADAIR, C. V., and DREISBACH, A. R. (I955), Amer. F. Hyg., 61, I63.
I8. HILLEMAN, M. R., WERNER, J. H., DASCOMB, H. E. BUTLER, R. L., and STEWART, M. T. (I955), Ibid., 62, 29.

19. GINSBERG, H. S., BADGER, G. F., DINGLE, J. H. JORDAN,'W. S., JR., and KATZ, S. (I955), F. Clin. Invest. 34, 820 .

20. BERGE, T. O., ENGLAND, B., MAURIS, C., SHUEY, H. E. and LENNETTE, E. H. (1955), Amer. $\mathscr{f} . H y g ., 62,283$.

21. HILLEMAN, M. R., WERNER, J. H., and STEWART M. T. (1955), Proc. Soc. exp. Biol., 90, 555.

22. GINSBERG, H. S., et al. (1955) Amer. F. publ. Hlth., 45, 915.

23. JORDAN, W. S., JR., BADGER, G. F. DINGLE, J. H. GINSBERG, H. S., and KATZ, S. (1954), f. Lab. clin. Med. 44,8 r 6 .

24. EVANS, A.S., and MORSE, H. (1955), Ibid., 46, 812.

25. SOUTHAM, C. M., HILLEMAN, M. R., and WERNER, J. H. (1956), Ibid., 47, 573.

26. DINGLE, J. H., and FELLER, A. E. (1956), New Engl. . Med., 254, 465 .

27. PARROTT, R. H., ROWE, W. P., HUEBNER, R. J. BERNTON, H. W. and MCCULLOUGH, N. M.'(I954), Ibid., 251 , 1087.

28. BELL, J. A., ROWE, W. P., ENGLER, J. I., PARROTT, R. H., and HUEBNER, R. J. (1955), F. Amer. Med. Ass. I57, 1083 .

29. TYRRELL, D. A. J., personal communication.

30. RYAN, R. W., O'ROURKE, J. F., and ISER, G. (r955), Arch. Ophthalmol., Chicago, 54, 2 I

31. ORMSBY, H. L. (1955), Canad. F. publ. Hlth., 46, 500.

32. HUEBNER, R. J., et al. (1955), F. Amer. Med. Ass., 159, 986.

33. JAWETZ, E., KIMURA, S., NICHOLAS, A. N., THYGESON, P., and HANNA, L.' (1955), Science, 122, I 190.

34. HILLEMAN, M. R., WERNER, J. H., DASCOMB, H. E. and BUTLER, R. L. (1955), Amer. F. publ. Hlth., 45, 203. 